\title{
"God save us always from the innocent and the good": American versus European Exceptionalism in Graham Greene's The Quiet American
}

\section{Thomas Ross Griffin ${ }^{1}$ iD}

Accepted: 25 May 2021 / Published online: 2 June 2021

(c) The Author(s) 2021

\begin{abstract}
This essay argues that by challenging the rectitude of American intervention in Vietnam, The Quiet American is the means by which Greene criticises the American exceptionalism of the post-World War 2 era. It shows how the nation's exceptionalism is built upon a fantasy of American idealism that masks the true intentions hidden behind America's crusade against Communism. It proposes also that Greene uses his novel to highlight the existence of a European exceptionalism as potent as its transatlantic equivalent, and one much overlooked in contemporary discourse on Vietnam. The crux of Greene's critique is located in Alden Pyle. Propped up by what Said describes as "structures of attitude and reference", the article argues that Pyle's rhetoric and actions demonstrate the blind commitment to American exceptionalism that Greene challenges in the text. The essay uses Donald Pease's concept of the State of Exception to draw a parallel between the British journalist Thomas Fowler and Pyle to argue that in orchestrating the assassination of the latter, Fowler adopts the moral purpose that had prompted much of the American aid worker's actions throughout the novel. It argues that this European version of exceptionalism comes from what Greene believed to be the suitability of European powers to oversee change in Vietnam, one that America was ill-equipped to handle. The essay ends by suggesting that The Quiet American was not so much what Diana Trilling described as "Mr Greene's affront to America", but an attempt to defend Europe amidst the onset of American dominance.
\end{abstract}

Keywords American exceptionalism · European exceptionalism · Graham Greene · Transatlantic literature · Vietnam War literature

Thomas Ross Griffin

rgriffin@qu.edu.qa

1 Department of English Literature \& Linguistics, College of Arts \& Sciences, Qatar University, Doha, Qatar 


\section{Introduction}

In the aftermath of World War II, the Marshall Plan underscored America's political, military and economic strength. This geo-political strategy, which reaffirmed the Americans' belief that only they had the resources and capability of defeating the global threat of socialism, would shape US foreign policy throughout the midtwentieth century. Although the Cold War between the USA and the Soviet Union never became "hot", it was frequently played out across theatres in Southeast Asia and Latin America. Eager to establish themselves as nations in their own right amidst political uncertainty caused by the demise of colonial rule, nations such as Vietnam presented an appealing battleground to the respective superpowers. Having lived in Saigon in the early Fifties, Graham Greene personally witnessed such turmoil as an increasingly dominant brand of American control displaced European hegemony in Vietnam. It was during this period that he wrote his controversial novel The Quiet American. The allegorical tale of a British journalist's efforts to fend off an American aid-worker's interest in his Vietnamese lover shone a very public light on Greene's opinion that US interference was to the detriment of the Southeast Asian state. This essay argues that by challenging the rectitude of American intervention in Vietnam, the novel is the means by which Greene criticises the American exceptionalism so prevalent in the mid-twentieth century. It suggests that the rationale motivating Greene's critique of American exceptionalism was not a "hatred for America's fight against communism", which W.J. West claimed was "inextricable from the fabric of The Quiet American."1 Rather I propose that the novel suggests the existence of a European exceptionalism every bit as worthy as its transatlantic equivalent, one that was quickly being overshadowed in the post-World War 2 era as America ascended to the role of global superpower.

\section{Alden Pyle and the good society of American values}

The crux of Greene's critique is most noticeably located in Thomas Fowler's reactions to the efforts of the American aid-worker, Alden Pyle, to expand what Seymour Martin Lipset describes as "the good society" of American values in Vietnam. Hoping to create a democratic Utopia in which virtues are promoted and all social evils are destroyed, Pyle embodies in The Quiet American the Manichean outlook common to the American exceptionalism of the mid-twentieth century. Pyle's tragic assumption, and that of many American lawmakers at the time, was that he knew what was best for nations such as Vietnam. Without any real-world example or evidence of a previous train of thought, he tells the British journalist, quite simply that "they don't want Communism." ${ }^{3}$ For Fowler however, this is merely the rhetoric

\footnotetext{
1 W.J. West, The Quest for Graham Greene (London: Weidenfeld \& Nicholson, 1997), 161.

2 Seymour Martin Lipset, 'Introduction: American Exceptionalism and Human Rights,' in American Exceptionalism and Human Rights, ed. Michael Ignatieff (Princeton: Princeton University Press), 21.

${ }^{3}$ Graham Greene, The Quiet American (Middlesex: Penguin, 1980), 94.
} 
of those who inhabit the "psychological world of great simplicity" that Greene saw as intrinsic to American exceptionalism.

Greene shows how this propensity to view the world in black and white terms would pervade every aspect of Pyle's life in Vietnam. Having travelled to Phat Diem to tell Fowler that he intends to pursue Phuong, Pyle's assumption is that not only will Phuong accept his advances, but that Fowler will also accept the end of his relationship with Phuong on the basis that Pyle can provide a better life for her in America. Regardless of the romantic relationship between Fowler and Phuong, Pyle insists that he was the one who understood more clearly what Phuong needed. As Fowler notes, "he was as incapable of imagining pain or danger to himself as he was incapable of conceiving the pain he might cause others." 5 This simplicity appears repeatedly throughout the novel, but most notably in the bizarre conclusions that Pyle draws from the botched bombing at Place Garnier. Fowler's scrutiny of Pyle's actions and the selective morality it practices culminates in a furious tirade against the American as he questions the former's right to impose his country's social structures and beliefs on nations such as Vietnam. He demands to know "how many dead colonels justify a child's ... death when you are building a national democracy?"6 Pyle's response is noticeably inadequate. In an effort to reconcile the death and injury caused by his actions with the integrity so fundamental to American exceptionalism, he ignores his own blunders by alleging that they were somehow the result of communist interference, a proposition immediately rejected by Fowler. Pyle later rewrites the narrative of the bombing to frame the civilian deaths as worthwhile sacrifices in the name of liberty. He tells Fowler that the Vietnamese victims "died in the right cause." 7

Pyle's response highlights what Greene saw as a disparity between the proposed morality allegedly motivating US foreign policy in Vietnam and the reality of its actions. This ability to extract value from such an obvious tragedy adheres to Lipset's argument that proponents of American exceptionalism view "social and political dramas as morality plays." 8 Fowler conveys his inability to comprehend this skewed American idealism with a damning response to Pyle's rationale: "I wouldn't know how to translate that into Vietnamese." the American. Pyle is incapable of conceptualising a reality any more nuanced than one that portrayed the USA as a lone good actor in a world full of those who sought to impede its progress. To acknowledge any of its inadequacies would undermine his almost sacred vision of his country as the only societal paradigm worthy of imitation by other nations.

\footnotetext{
${ }^{4}$ Greene, Quiet American, 85.

5 Greene, Quiet American, 62.

${ }^{6}$ Greene, Quiet American, 163.

7 Greene, Quiet American, 179.

8 Lipset, 'Introduction,' 22.

9 Greene, Quiet American, 179.
} 


\section{An exceptional America?}

Pyle's lofty opinion of his country stemmed from the steadfast belief that American society was inherently superior to its European equivalent. Despite having benefitted greatly from centuries of "European ideas, institutions, inventions and ways of thinking", ${ }^{10}$ from the American point of view, it was devoid of the cultural failings which had debased the Old World society. But using Fowler as a mouthpiece, Greene challenges the validity of this claim that America is "the only political, cultural, and economic model [which] the rest of the world"11 should aspire to imitate. Yet as this essay argues, Greene shows how the nation's exceptionalism is built upon a fantasy of American idealism that masks the true intentions hidden behind America's crusade against Communism.

\section{America's colonial past}

Donald Pease states in The New American Exceptionalism that, unlike the traditional colonial powers of Europe, one of the core beliefs of American exceptionalism was that the USA "was different ... in that it repudiated the acquisition of colonies." 12 Being a former colony itself, the US was sympathetic to the plight of nations such as Vietnam emerging onto the world stage. Consequently, any intervention the US made overseas was not to exploit such countries, but to share with them their own experiences in making the transition from colony to self-rule. In contrast to centuries of harsh and often bloody colonialism that had rendered the French and British unsuited to this task, America's revolutionary origins, its transformation into a global power, and its absence of a colonial history meant that it was ideally placed to provide the social and moral blueprint for these young nations to follow.

But this claim to be able to enter a complex geo-political arena such as Vietnam in the 1950s with what Pyle described as "a clean pair of hands" 13 is one contested by Greene in The Quiet American. Despite America's own struggles for independence from British rule, Greene demonstrates how adept it had become at imposing its own political will, either militarily or ideologically, on smaller or bordering nations. In response to hearing of how Pyle was extolling the advantages of a spotless colonial past to a number of US politicians, Fowler quickly reels off a succession of interventions where American assistance ultimately resulted in a direct increase in American hegemony. As Fowler comments, for the inhabitants of "Hawaii, Puerto

\footnotetext{
${ }^{10}$ Hans R. Guggisberg, 'American Exceptionalism as National History?', in Bridging the Atlantic: The Question of American Exceptionalism in Perspective, ed. Elisabeth Glaser and Hermann Wellenreuther, (Cambridge: Cambridge University Press, 2002), 265.

${ }^{11}$ Meghana V. Nayak and Christopher Malone. 'American Orientalism and American Exceptionalism: A Critical Rethinking of US Hegemony,' International Studies Review 11, (2009): 260.

12 Donald Pease, The New American Exceptionalism (Minneapolis: University of Minneapolis Press, 2009), 13.

${ }^{13}$ Greene, Quiet American, 124.
} 
Rico ... [and] New Mexico", ${ }^{14}$ there was little discernible difference between the old-fashioned European colonialism and the strategies used by the US to further extend their own sphere of influence.

Fowler is also acutely aware of the fact that at the time, Vietnam was predominantly agrarian and steeped in tradition, and thus vastly different to the modern America of "the skyscraper and the express elevator, the ice cream and the dry Martinis." 15 Overseeing badly designed aid programmes such as those which provided "electrical sewing machines for starving seamstresses" 16 in villages without electricity, Greene highlights how little understanding Americans such as Pyle had of those living in nations struggling to emerge from colonial rule such as Vietnam. Rather than addressing the issues on the ground at the time, widespread poverty, organised crime and corruption, and a rising swell of nationalist pride increasingly more infused by socialism, the American Economic Mission attempts to use the $20^{\text {th }}$-century trappings of the West as a distraction. As Fowler describes a Vietnamese society overrun by "private stores of Coca-cola and their portable hospitals and their too wide cars and their not quite latest guns." 17 Frantz Fanon's words from The Wretched of the Earth come to mind. Fanon spoke of how at the onset of a colonial endeavour, what are first commonly put in place are "a project of economic and social reforms which will satisfy the aspirations of the colonized people." 18 Awash with the abundance of Western culture, the intention is to demonstrate the superiority of the alien society, yet as Fanon goes on to state, this largesse has a hidden motive. What he describes as "the total result looked for" was in fact "to convince the natives that colonialism came to lighten their darkness." 19 Such a dynamic is apparent in The Quiet American. Automobiles become a routine sight in the Mekong Delta, while showbands and milk bars become established parts of Saigon society. It is clear that America's consumer culture was practicing a similar strategy in 20th-century Vietnam to its European predecessors as it eroded multiple aspects of the Southeast Asian nation's deeply spiritual and feudal culture. Whether operating under the moral premise of exceptionalism or self-serving colonialism, each involved the use of a state-sanctioned fantasy "to dignify simple conquest with an idea, to turn the appetite for more geographical space into a theory about the special relationship between geography ... and civilised or uncivilised people." ${ }^{, 20}$ For critics such as Greene, there was little to choose between the colonial fervour that gripped nineteenth-century Europe and the American exceptionalism that propelled American foreign policy overseas a century later.

Yet Pyle insists upon the America's superiority to oversee this transition of Vietnam from colonial dependency to national democracy. The belief system he

\footnotetext{
14 Greene, Quiet American, 124.

15 Greene, Quiet American, 20.

16 Greene, Quiet American, 41.

17 Greene, Quiet American, 31.

18 Frantz Fanon, The Wretched of the Earth (London: Penguin, 2001), 167.

19 Fanon, The Wretched, 169.

${ }^{20}$ Edward Said. Orientalism (London: Penguin, 2003), 216.
} 
embodied was devoid of the feudalistic shortcomings of Europe's "stuffy colonialism" 21 because it endeavoured to create a rapport between the two nations built on American equality and democracy. In promoting idealistic maxims such as "a man becomes trustworthy when you trust him", ${ }^{22}$ Pyle and his countrymen hoped to wean the native population away from European modes of thinking and encourage them to adopt the apparently more desirable and undeniably more idealistic American values. Even should this not occur, advocates of American exceptionalism such as Pyle could be consoled by the comfort that, due to the obvious benevolence of their actions, the native population of Vietnam would still recognise and respect the altruism of their intentions. As Pyle declares to Fowler; "at least they won't hate us like they hate the French." 23

But this interpretation of difference between New and Old World is one fiercely contested by Greene. He recognises the building of an empire, one that sought to impose an alien set of beliefs and practices on the Vietnamese people, and one that would meet as much internal resistance as its colonial predecessors. Fowler tries to explain to an oblivious Pyle that to the Vietnamese, the aid worker merely represents yet another iteration of Western values forced upon the Southeast Asian nation. He tells him that much like the French before them, the Americans in Vietnam are simply just another generation of "white skins ... telling them what they want." ${ }^{24}$ As was the case with the generations of Europeans before them, the American presence in Vietnam was not a new dawn but rather emblematic of a longstanding racial hierarchy that prioritised the cultural values of the Caucasian West.

Greene underscores this dynamic in describing the final confrontation between Fowler and Pyle that takes place in Fowler's apartment in which they discuss their intentions for Phuong's future. Just as she was symbolically denied the act of expression for much of the novel, Phuong, as the metonymic representation of Vietnam, is notably absent from this pivotal scene. Yet her fate is still decided by the two interlopers who only ever view her in the abstract sense of something to be owned and controlled. As the discussion on Phuong ends, the transfer of ownership from Fowler to Pyle, Europe to America, is complete, and Pyle carries on the paradigm of patriarchal domination that had defined Western attitudes to the region for centuries. He speaks for her because he believed that her answer would only confirm what each he already felt to be true and correct. Despite having already rejected Pyle's earlier proposal of marriage, the manner in which her future is decided mirrors the status of her people, who were "dominated by a race who knows them and what is good for them better than they could possibly know themselves." ${ }^{25}$ As the novel closes, the similarity in their respective world-views between Fowler and Pyle, one derived from a sense of superiority towards the "Other", becomes even more pronounced.

\footnotetext{
21 Greene, Quiet American, 146.

22 Greene, Quiet American, 86.

23 Greene, Quiet American, 176.

${ }^{24}$ Greene, Quiet American, 94.

25 Said, Orientalism, 35.
}

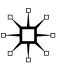


Irrespective of their political outlooks, as Fowler tells Pyle, to the Vietnamese people "you are a European too." 26

Negating this supposed transcontinental superiority was not an exercise Greene confined to The Quiet American, as a letter to The New Statesman over a decade later concerning the ongoing American presence in Vietnam reveals. Here, he noted that the implementation of American values on Vietnamese society had "not brought freedom from war or from hunger ... [and had] certainly not brought freedom to choose a government." ${ }^{27}$ Rather, US interference in Vietnam had merely repeated the pattern of famine, conflict, and political corruption that had characterised French colonial rule. Greene acknowledged that America now occupied the position of authority once held by traditional European powers, he saw no obvious improvement for the people of Vietnam. While the Americans sought to distance themselves from their colonial peers by emphasizing the unselfish concerns of their actions, Greene's interpretation of their presence in Vietnam is clear. As long as Americans were present in the Southeast Asian nation, the Vietnamese were still subjects to at least one of what Edward Said described as the "three great empires-British, French, American", ${ }^{28}$ and thus the lot of the Vietnamese people would remain unchanged.

\section{America as an example}

The belief that the USA presented the only social model worth imitating is another pressing critique found within The Quiet American of American exceptionalism. The novel was written between 1952 and 1955 during a time of immense political turmoil in the USA. The Civil Rights Movement began to gain momentum in its demand to end racial discrimination and bring an end to the era of Jim Crow. McCarthyism was also rife during this period, a movement that resulted in the persecution of American citizens from all classes of society on suspicion of ties to socialism. That problems such as these existed in their society suggested a crucial failing of American exceptionalism to critics like Greene. Namely, that there was a naive inability, or even worse, an unwillingness, by the US to reconcile the idealism of their belief systems with the ugly realities of the world around them.

The novel highlights what Greene saw as this inclination by American actors to promote idealised social models such as American exceptionalism rather than confront inconvenient realities. The cause of Pyle's death lay not so much in his actions, according to Fowler, but more so in how he looked at the world. His aspiration is to create a "Third Force ... free from Communism and the taint of colonialism"29 in Southeast Asia that would adopt and perpetuate American values of liberty and democracy. Emerging from a school of thought that urged its followers to take "an

\footnotetext{
26 Greene, Quiet American, 95.

27 Graham Greene, Yours etc.: Letters to the Press, (London: Reinhardt-Viking), 119.

28 Said, Orientalism, 15.

${ }^{29}$ Greene, Quiet American, 124.
} 
idea and then alter every situation to fit the idea", ${ }^{30}$ Pyle is incapable of recognising that this abstract geo-political strategy designed by York Harding to combat communism in Vietnam was entirely ill-suited to the situation on the ground at the time. The reality of the situation is quite different, as Fowler explains to the American aid-worker, "This Third Force, it comes out of a book, that's all. General Thé's a bandit with a few thousand men: he's not a national democracy." 31 Fowler's interpretation of events is true to reality as repeated bombings throughout the city of Saigon to advance his own interests demonstrate General Thé's disregard for American instruction and leadership. Yet Pyle remains "impregnably armoured by his good intentions and his ignorance." $32 \mathrm{He}$ is convinced that the errant general remains committed to the cause of democracy in Vietnam, and that anything to the contrary was the work of communist forces. Rather than face a reality that might challenge his outlook on the world, Pyle instead chooses to construct a reality that adheres to a Manichean belief system of exceptionalism that posits America, and its allies, as forces for good.

Pyle's portrayal as a character who prefers to participate in fantasy rather than engage with reality is a forceful critique of American culture within the novel. As Stephen Whitfield notes, Pyle "is an anti-Communist, anti-colonialist interventionist, wreaking havoc because he can only grasp the struggle as an abstraction." 33 This is his primary weakness. He is the embodiment of this ideology engaged in the fight against communism throughout the text. Yet his qualification for such a politically sensitive role are fields of study concerned more with the representation of reality than reality itself, derided by Fowler as "one of those subjects Americans can take degrees in: perhaps public relations or theatre-craft." 34 This subtle attack on American culture is just one iterance of Fowler's propensity "to run down everything that was American." "35 As he goes on to state, "my conversation was full of the poverty of American literature, the scandals of American politics, the beastliness of American children. ... Nothing that America could do was right." 36 This critique extends to a description of Pyle's personal library. Dominated by works on US foreign policy, Vietnamese phrasebooks and Congressional reports, they also inform Pyle's plot to form an American-led force with which to rule Vietnam.

Despite the didactic nature of his bookshelf, including texts such as "The Advance of Red China", 37 the catastrophic ramifications of Pyle's Place Garnier collusion with General Thé demonstrate that the education they provide is wholly inadequate in dealing with the complexities of the Orient and the yawning chasm between fantasy and reality existing within American exceptionalism. Based on

\footnotetext{
${ }^{30}$ Greene, Quiet American, 167-168.

31 Greene, Quiet American, 157.

32 Greene, Quiet American, 163.

33 Stephen Whitfield, 'Limited Engagement: The Quiet American as History,' Journal of American Studies 30, no. 1 (April 1996): 68.

${ }^{34}$ Greene, Quiet American, 21.

35 Greene, Quiet American, 140.

36 Greene, Quiet American, 140.

37 Greene, Quiet American, 28.
} 
American interpretations of Asian society, these texts describe an idealised world where US control is uncontested. In the context of The Quiet American, they acquire the status that Said bestowed upon the $19^{\text {th }}$-century novel in relation to the colonial world. They become "structures of attitude and reference." ${ }^{38}$ For Said, such structures are intertwined with attitudes "about rule, control, profit, and enhancement and suitability" "39 and contribute towards the shaping of a society's cultural identity. He goes on to say that within these structures, "there was virtual unanimity that subject races should be ruled, that they are subject races, that one race deserves and has consistently earned the right to be considered the race whose main mission is to expand beyond its own domain." 40 Pyle's rhetoric and his actions propose a blind commitment to such a view. Texts such as "The Challenge to Democracy" and "The Role of the West" 41 suggest a social hierarchy that would have placed America at its peak as a benevolent overseer of those less fortunate. Furthermore, they would have helped consolidate a cultural identity at the time in keeping with America's own vision of itself as a global policeman, a force for good in the world that upheld standards of behaviour that had been ignored or let slide by previous powers. This in itself reflects the fantasy inherent in American exceptionalism that Greene so persistently refutes throughout his novel. There is little to show for US efforts in the wake of Pyle's actions in Vietnam bar a growing death count and greater social upheaval. The Vietnamese do not perceive him to be a saviour, and the American presence in Vietnam is not better than those that came before them. Rather, it is merely just another Western intrusion upon their society to tolerate until it ultimately ceases.

\section{A "State of Exception"}

At the centre of Greene's argument was what he saw as the American propensity to do great harm in the name of doing great good, an attribute that Fowler observes in Pyle, stating that "I never knew a man who had better motives for all the trouble he caused." 42 For Pyle to act in this fashion however was not anomalous. It is rather an intrinsic part of American exceptionalism as Donald Pease explains in The New American Exceptionalism. Here, he states that.

American exceptionalism has been taken to mean that America is "distinctive" (meaning different), or "unique" (meaning anomalous), or "exemplary" (meaning a model for other nations to follow), or that it is "exempt" from the laws of historical progress (meaning that it is an "exception" to the laws and rules governing the development of other nations). ${ }^{43}$

\footnotetext{
38 Edward Said, Culture \& Imperialism, (London: Vintage, 1994), 62.

39 Said, Culture, 61.

40 Said, Culture, 62.

41 Greene, Quiet American, 28.

42 Greene, Quiet American, 60.

43 Pease, New, 9.
} 
More clearly stated, Pease argues that America's exceptionalism signifies that as a nation, America believes itself to be different and better than other nations, and most importantly, not beholden to the laws and rules that the rest have to obey. It is this third interpretation of the term "exceptionalism" that offers not only the greatest nuance, but also the version most embodied by Alden Pyle in The Quiet American. This third and final reading of the term allowed Americans to envision themselves as "protectors of a political culture" 44 who identified and utilised "illiberal measures as the sole way to protect and guarantee ... liberal values." 45 This created a "State of Exception" 46 for many Americans. This is when the actions of the state, and also actions taken by its agents, are viewed as exceptions from those permitted by the everyday laws of state. Crucially, it reframed actions not in keeping with idealised American beliefs as necessary to preserve the nation's exceptional status and its hegemony overseas. The bombing of Place Garnier, and Pyle's limp defence of this act thereafter is the novel's most telling example of such an action and the obvious source of much of the author's ire. However, Greene's distaste for what he perceived to be the hypocrisy of American exceptionalism is quite clear at this juncture. What has received much less attention since the novel's publication in 1955 is The Quiet American's representation of a similar sense of exceptionalism albeit one whose locus is on the opposite side of the Atlantic.

\section{European states of exception}

The most conclusive factor pointing towards the presence of a European form of exceptionalism is Fowler's eventual decision to become as "engagé" 47 or involved in the affairs of Vietnam as his American counterpart. Throughout the text, this had always been the key distinction between the British journalist and Pyle. The latter "believed in being involved." 48 For Fowler however, "it had been an article of my creed. The human condition being what it was, let them fight, let them love, let them murder, I would not be involved." ${ }^{49}$ However, as the novel ends, this self-imposed rule is broken as the intrinsic morality motivating Pyle to save Vietnam from itself now becomes apparent in his transatlantic rival. Yet rather than defending Vietnam from the dangers of atheism and communism, Thomas Fowler can be seen as endeavouring to protect what he saw as a weaker nation from a New World idealism he viewed as being both destructive and misguided. Appropriating Pyle's urge "to do good ... to a country, a continent, world", ${ }^{50}$ Fowler plays a fundamental part in arranging Pyle's assassination. Emerging from the aftermath of the Place Garnier

\footnotetext{
44 Pease, New, 25.

45 Pease, New, 26.

46 Pease, New, 23.

47 Greene, Quiet American, 97.

48 Greene, Quiet American, 29.

49 Greene, Quiet American, 28.

50 Greene, Quiet American, 18.
}

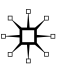


bombing, outraged at the feeble excuses offered by Pyle in defence of his actions, Fowler's immediate reaction is to seek out Mr Heng with the intention of stopping any further damage. Although having ample opportunity to warn Pyle of his fate during their final meeting, the American's opinion that those killed at Place Garnier "died for democracy" 51 and also his refusal to cut ties with General Thé overwhelm any doubts that Fowler may have had about his actions. His commitment to what he knows will be the murder of Alden Pyle is a stark contrast to the man appalled at the needless loss of life he sees in Phat Diem, who proclaims to hate war, and who is quick to castigate his American companion for the violence of his methods. Fowler's closing words on Pyle reveal a final affirmation of his own actions. Imagining Pyle one last time, "a young man with a crew-cut and a black dog at his heels", Fowler's thoughts are "he could harm no one any more." 52

In orchestrating the assassination of Pyle, the British journalist adopts the moral purpose that had prompted much of the American aid worker's actions throughout the novel, particularly the bombing at Place Garnier. In doing so, it can be argued that both men inhabit Pease's "State of Exception." In such a domain, government representatives such as Pyle are unable to discern a difference between their own will and that of the state. Even when they commit transgressions that would be considered terrible crimes in normal society, they are both protected from the immediate consequences of their actions. Yet as a representative of Europe, Fowler too occupies such a state. Gone are the vestiges of guilt apparent throughout the novel as Fowler witnesses unparalleled and needless death. The social conscience that harangued Pyle in the aftermath of Place Garnier has been silenced. Just as Pyle sought to deflect the blame for his schemes onto the communists, Fowler too seeks to repel any responsibility for his actions onto the Americans who sent the aidworker to Vietnam. Both York Harding and the American government are assigned blame for shaping Pyle's worldview and then sending him to Vietnam to implement it. Shielded by a belief system that imbues their task with a moral purpose, their deeds and the ensuing consequences are deemed sacrifices made for the greater good of society. Fowler resides as the novel ends in this exact space. Thus, when the mutual condescension, orientalism, and misguided morality of both men are viewed in tandem, a massive leap is not required to interpret the novel as Greene's effort to demonstrate a European exceptionalism capable of offering an alternative to its transatlantic rival.

\section{European exceptionalism}

These actions by Fowler are surprising given his repeated refusal to become involved in the affairs of others. Why would Greene allow his protagonist to commit such a volte-face? A possible answer might be that he saw America as ill-equipped to oversee change in Vietnam, and that European culture was much better suited to

\footnotetext{
51 Greene, Quiet American, 179.

52 Greene, Quiet American, 188-189.
} 
the task. This view is suggested by Greene himself when discussing the American intervention in Vietnam as they "may mean well, but they are naive, and in any case benevolence is dangerous if it is an expression of a twisted view of the desirable life." ${ }^{, 53}$ Europe, as the antithesis of America, by way of contrast, offered a more erudite approach to Vietnam, one learned from centuries of colonial rule and equipped with an innate and truer understanding of how to manage Vietnamese society. More succinctly put, in dealing with the affairs of the world beyond the vast expanses from New York to San Francisco, Europe was superior to America. It had more experience, more knowledge, and more understanding of what was required to "manage" those younger nations taking their first steps out of colonialism. In The Quiet American, Fowler, a figure to whom the Americans are as much the childlike "Other" as the Vietnamese, personifies these attributes. This dynamic, which exists throughout the novel in the relationship between Fowler and Pyle, is essential to understanding Greene's attempt to communicate the advantages of European exceptionalism. Much as he did so with Phuong, Fowler infantilises Pyle, viewing him as one would view a small child, well-intentioned, but often clumsy in their actions. Pyle is "a hero in a boy's adventure story, proud of his caution like a Scout's badge and quite unaware of the absurdity and the improbability of his adventure", 54 forever young and naïve when set alongside the worldly Fowler. He actively seeks out the British journalist upon his arrival in Saigon in order to familiarise himself with the city. When explaining the war between the French and the Viet Minh, Fowler notes how Pyle "watched me intently like a prize pupil." 55 As their relationship grows closer, Fowler has the epiphany "that was my first instinct - to protect him," from himself as those around him as he unknowingly blunders through the sociopolitical structures of Vietnam. This is a realisation that quickly comes to pass when both men are left stranded en route home from a religious ceremony in the Mekong Delta. They shelter in a nearby watch-tower manned by two frightened Vietnamese soldiers. As Fowler and Pyle debate the merits of the American approach to Vietnam against that used by the French, Fowler demonstrates an understanding of the nuances of Vietnamese society that Pyle simply does not have. It is Fowler who understands the gravity and danger they were in, even in friendly territory, and it is Fowler who has the foresight to realise that discretion rather than valour is the only way to survive the night that follows, despite the insistence of Pyle to the contrary. When the Viet Minh arrive, at Fowler's insistence both he and Pyle jump from the watch-tower to take refuge in a nearby paddy field, abandoning the two Vietnamese guards to their fate.

This incident is just one example of Fowler demonstrating a laissez-faire attitude towards Vietnam and its culture that it seems Alden Pyle is incapable of practicing. In doing so, Greene implicitly asserts the superiority of Europe as an overseer more

\footnotetext{
53 Anthony Burgess, 'Politics in the Novels of Graham Greene,' Journal of Contemporary History 2, no.

2, (April 1967): 96.

54 Greene, Quiet American, 113.

55 Greene, Quiet American, 24.

56 Greene, Quiet American, 37.
}

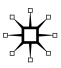


fit for purpose in Southeast Asia than its American equivalent. Having lived in Vietnam for a number of years, Fowler realises that the ordinary Vietnamese person was more concerned with mundane matters such as the well-being of his family, land, and livestock rather than the complex geo-political struggle being played out by the global superpowers. He knows that any conflict within Vietnam should be left to the Vietnamese, and that outside interference of any kind merely acts to make the situation worse. Far from concerned with the vagaries of democracy, or the necessity of a Third Force as Pyle so adamantly insists, Fowler understood both the requirements of the Vietnamese people at that moment, and just as importantly, the unsuitability of American efforts to force any such change on their society.

The advantages held by Europe over their transatlantic rivals are also manifest in the use of language throughout the text. The common use of French between Fowler, Vigot, and the Vietnamese, and the obvious inability of the Americans to master it enacts an important paradigm that adheres to the premise that Greene sought to express a European exceptionalism in his novel. Repeatedly met with confusion and silence whenever he attempts to speak the language with Phuong, or any other Vietnamese characters in the text, Pyle frequently has to turn to Fowler to translate for him. The symbolism is clear. While some Americans may have seen Thomas Fowler and Inspector Vigot as fading embers of colonial power, they act as interpreters of Vietnam to men such as Pyle. Extending the teacher-student metaphor almost to the point of farce, this dynamic is repeated as Pyle sequesters Fowler to translate his marriage proposal to Phuong. Refused, the American remains symbolically estranged from the ancient society of Vietnam. He is ultimately isolated, unable to listen to the people of Vietnam, unable to learn what they truly want. This isolation is one heavily juxtaposed by the physical relationship between Fowler and Phuong, a metaphorical re-enactment, from a patriarchal European standpoint at least, of the shared history and closeness between the Old World and its colonies. The symbolic accrual of over a century of colonial rule, it could be argued possessed by actors such as Fowler, and to a lesser extent, Inspector Vigot, European exceptionalism demonstrates a familiarity and understanding that doesn't just highlight the advantages it holds over its new-age American counterpart. It also imbues their knowledge of the Vietnamese Other with a familiarity that is sympathetic to the requirements of Vietnamese society at that juncture in the twentieth century.

In the competition to decide which ideology is best suited to nations such as those found in Southeast Asia, it is clearly evident that Greene understood the European approach as most appropriate to the task. One final look at the novel's conclusion would appear to support this assertion. Fowler's inability to fully commit to Phuong, as well as Pyle's offers of "security and respect", 57 results in the temporary loss of the Vietnamese girl to his transatlantic rival. However, Fowler violates his principle of becoming involved and plays a fundamental part in orchestrating Pyle's death at the hands of the Viet Minh. As a result, as the novel ends, the British journalist regains his native prize and Europe's status as the pre-eminent power in Vietnam is restored. In comparison, the novel's living embodiment of American exceptionalism suffers a fate predicted by Michael Ignatieff. He states that "the critical cost that

57 Greene, Quiet American, 79. 
America pays for exceptionalism is that this stance gives the country convincing reasons not to listen and learn. Nations that find reasons not to listen and learn end up losing." 58 Steadfast in his refusal to heed Fowler's warning that "you and your like are trying to make a war with the help of people who just aren't interested", 59 Pyle too eventually loses as he perishes alone in the mud of the Dakow river.

\section{Conclusion}

The Quiet American was written at a time when Britain was at one of its lowest ebbs. While World War II had ended in an Allied victory over Nazi Germany, the rebuilding process in Europe was dependent to a large extent on American generosity. In addition, although once dominant, British and European colonial power was now rapidly fading as a hegemonic realignment in favour of the USA became an inevitable reality. While many nations and their citizens were benefitting from the rise of the US in the aftermath of the war, by being blacklisted from America throughout the Fifties, ${ }^{60}$ the positives Greene could have drawn from this American ascension were minimal, if any at all. It is within this context, with Greene located both physically and existentially on the margins of the New World Order which America sought to create, that the novel should be viewed. Denied access to the Utopian society being created by the US in the middle of the twentieth century, Greene became intent on promoting an idea of Europe not as a continent weak and lost to past glories, but one as worthy if not better than its transatlantic peer. As such, The Quiet American's critique of American exceptionalism was not so much what Diana Trilling described as "Mr Greene's affront to America", but one of the most famous iterations of an unfavourable view of American society when set alongside Europe, a theme that Greene would repeatedly return to throughout the remainder of his life.

Funding Open access funding provided by the Qatar National Library.

Open Access This article is licensed under a Creative Commons Attribution 4.0 International License, which permits use, sharing, adaptation, distribution and reproduction in any medium or format, as long as you give appropriate credit to the original author(s) and the source, provide a link to the Creative Commons licence, and indicate if changes were made. The images or other third party material in this article are included in the article's Creative Commons licence, unless indicated otherwise in a credit line to the material. If material is not included in the article's Creative Commons licence and your intended use is not permitted by statutory regulation or exceeds the permitted use, you will need to obtain permission directly from the copyright holder. To view a copy of this licence, visit http://creativecommons.org/licen ses/by/4.0/.

\footnotetext{
58 Greene, Quiet American, 26.

59 Greene, Quiet American, 94.

60 Norman Sherry, The Life of Graham Greene Volume 3 1955-1991, (London: Random House, 2016), 14-15.
}

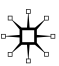




\section{References}

Burgess, Anthony. "Politics in the Novels of Graham Greene." Journal of Contemporary History 2, no. 2, Literature and Society (April 1967): 93-99. https://doi.org/10.1177/002200946700200208

Fanon, Frantz. 2001. The Wretched of the Earth. London: Penguin.

Greene, Graham. 1980. The Quiet American. Middlesex: Penguin.

Greene, Graham. Yours etc.: Letters to the Press. Ed. Christopher Hawtree. London: Reinhardt-Viking, 1989.

Guggisberg, Hans R. 2002. American Exceptionalism as National History? In Bridging the Atlantic: The Question of American Exceptionalism in Perspective, ed. Elisabeth Glaser and Hermann Wellenreuther, 265-276. Cambridge: Cambridge University Press.

Ignatieff, Michael. 2005. Introduction: American Exceptionalism and Human Rights. In American Exceptionalism and Human Rights, ed. Michael Ignatieff, 1-27. Princeton: Princeton University Press.

Lipset, Seymour Martin. 1991. American Exceptionalism Reaffirmed. In Is America Different? A New Look at American Exceptionalism, ed. Byron E. Shafer, 1-45. Oxford: Clarendon.

Nayak, Meghana V., and Christopher Malone. 2009. American Orientalism and American Exceptionalism: A Critical Rethinking of US Hegemony. International Studies Review 11: 253-276.

Pease, Donald E. 2009. The New American Exceptionalism. Minneapolis: University of Minneapolis Press.

Said, Edward W. 1994. Culture \& Imperialism. London: Vintage.

Said, Edward W. 2003. Orientalism. London: Penguin.

Sherry, Norman. 2016. The Life of Graham Greene Volume 3 1955-1991. London: Random House.

Trilling, Diane. "On the Horizon: America and The Quiet American." Commentary, July 1956. https:// www.commentarymagazine.com/articles/diana-trilling/on-the-horizon-america-and-the-quiet-ameri can/

West, W.J. 1997. The Quest for Graham Greene. London: Weidenfeld \& Nicholson.

Whitfield, Stephen. "Limited Engagement: The Quiet American as History." Journal of American Studies 30, no. 1 The American Past and Popular Culture (April 1996): 65-86. https://doi.org/10.1017/ S0021875800024324

Publisher's Note Springer Nature remains neutral with regard to jurisdictional claims in published maps and institutional affiliations.

Thomas Ross Griffin is an early-career academic who teaches American Literature and Postcolonial Literature in Qatar University. He has published work on a broad range of subjects ranging from Orientalism in the British broadsheet press in the twenty-first century to the soft power implications of the Marvel Superhero Universe in peer-reviewed journals and edited university press collections as well as for international news media. His research interests include the portrayal of the Arab world in Western media, the relationship between sport and postcolonial society, and national identity in the GCC. 